\title{
Structural elements of the Streptomyces oriC region and their interactions with the DnaA protein
}

\author{
Dagmara Jakimowicz, ${ }^{1}$ Jerzy Majka, ${ }^{1,2}$ Walter Messer, ${ }^{2}$ Christian Speck, ${ }^{2}$ \\ Marisol Fernandez, ${ }^{3}$ M. Cruz Martin, ${ }^{3}$ Jesus Sanchez, ${ }^{3}$ \\ Florian Schauwecker, ${ }^{4}$ Ullrich Keller, ${ }^{4}$ Hildgund Schrempf ${ }^{5}$ \\ and Jolanta Zakrzewska-Czerwińska'
}

1 Ludwik Hirszfeld Institute of Immunology and Experimental Therapy, Polish Academy of Sciences, ul. Weigla 12, 53-114 Wroclaw, Poland

2 Max-Planck-institut für Molekulare Genetik, Ihnestraße 73, D-14195 Berlin-Dahlem, Germany

3 Departamento de Biologia Funcional e Instituto Universitario de Biotecnologia de Asturias, Universidad de Oviedo, J. Claveria 6, Oviedo 33006, Spain

4 Max-Volmer-Institut für Biophysikalische Chemie und Biochemie, Fachgebiet Biochemie und Molekulare Biologie, Technische Universităt Berlin, Franklinstrasse 29, D-10587 Berlin, Germany

5 Fachbereich

Biologie/Chemie, Universităt Osnabrück, Barbarastraße 11, 49069 Osnabrück, Germany

Author for correspondence: Jolanta Zakrzewska-Czerwińska. Tel: +48716790 81. Fax: +4871679111. e-mail: zakrzew@immuno.iitd.pan.wroc.pl

\begin{abstract}
Streptomycetes differ from other prokaryotic organisms in their mycelial life cycle and in possessing a large, linear, GC-rich chromosome. To deduce structural features of the Streptomyces origin of chromosomal replication, the oriC sequences of three Streptomyces species (S. antibioticus, S. chrysomallus and S. Iividans) were compared. In Streptomyces, the oriC region contains 19 DnaA boxes whose location, orientation and spacing are conserved. The consensus sequence of the DnaA box identified within Streptomyces oriC is $(\mathrm{T} / \mathrm{C})(\mathrm{T} / \mathrm{C})(\mathrm{G} / \mathrm{A} / \mathrm{C})$ ICCACA (preferred bases underlined). The interactions of DnaA with DNA fragments containing single, two or three DnaA boxes were studied using surface plasmon resonance. The dissociation constant $\left(K_{0}\right)$ for specific binding of individual DnaA boxes varied between 12 and $78 \mathrm{nM}$. Streptomyces oriC does not contain the three AT-rich 13-mer direct repeats present in the $5^{\prime}$ part of the Escherichia coli oriC region. However, short AT-rich sequences are distributed among the DnaA boxes of Streptomyces oriC. Repeated attempts to unwind Streptomyces oriC have been unsuccessful. It remains to be elucidated whether DnaA interacts with putative accessory proteins which help in unwinding Streptomyces oriC.
\end{abstract}

Keywords: DnaA box, AT-rich sequence, oriC, Streptomyces

\section{INTRODUCTION}

Streptomycetes are Gram-positive soil bacteria that grow as substrate mycelia differentiating to aerial mycelia and spores upon depletion of nutrients (Kützner, 1981). These bacteria differ from other prokaryotes not only in their mycelial life cycle but also in possessing a large (6-8 Mb), GC-rich chromosome, which has been found in linear form (Leblond et al., 1993; Lin et al., 1993; Lezhava et al., 1995).

Abbreviations: BD, binding domain; GST, glutathione S-transferase.

The GenBank accession numbers for the sequences reported in this paper are AF026792 (Streptomyces antibioticus), AF027658 (Streptomyces chrysomallus) and M86491 (Streptomyces fividans).
In bacteria, chromosome replication is initiated at the replication origin, oriC, and the process is highly regulated (for review, see Kornberg \& Baker, 1992; Messer \& Weigel, 1996). The structure of the oriC region has been analysed within Gram-negative and Gram-positive bacteria. The sequences of ori $C$ regions are conserved only among closely related organisms (Yoshikawa \& Ogasawara, 1991). Sequence analyses have revealed that the origins of various eubacteria contain short, conserved sequences which are essential for oriC function: non-palindromic 9 bp sequences, socalled DnaA boxes and AT-rich regions (Yoshikawa \& Ogasawara, 1991; Messer \& Weigel, 1996). These conserved sequences are separated by spacer regions which vary in nucleotide composition and length. A 


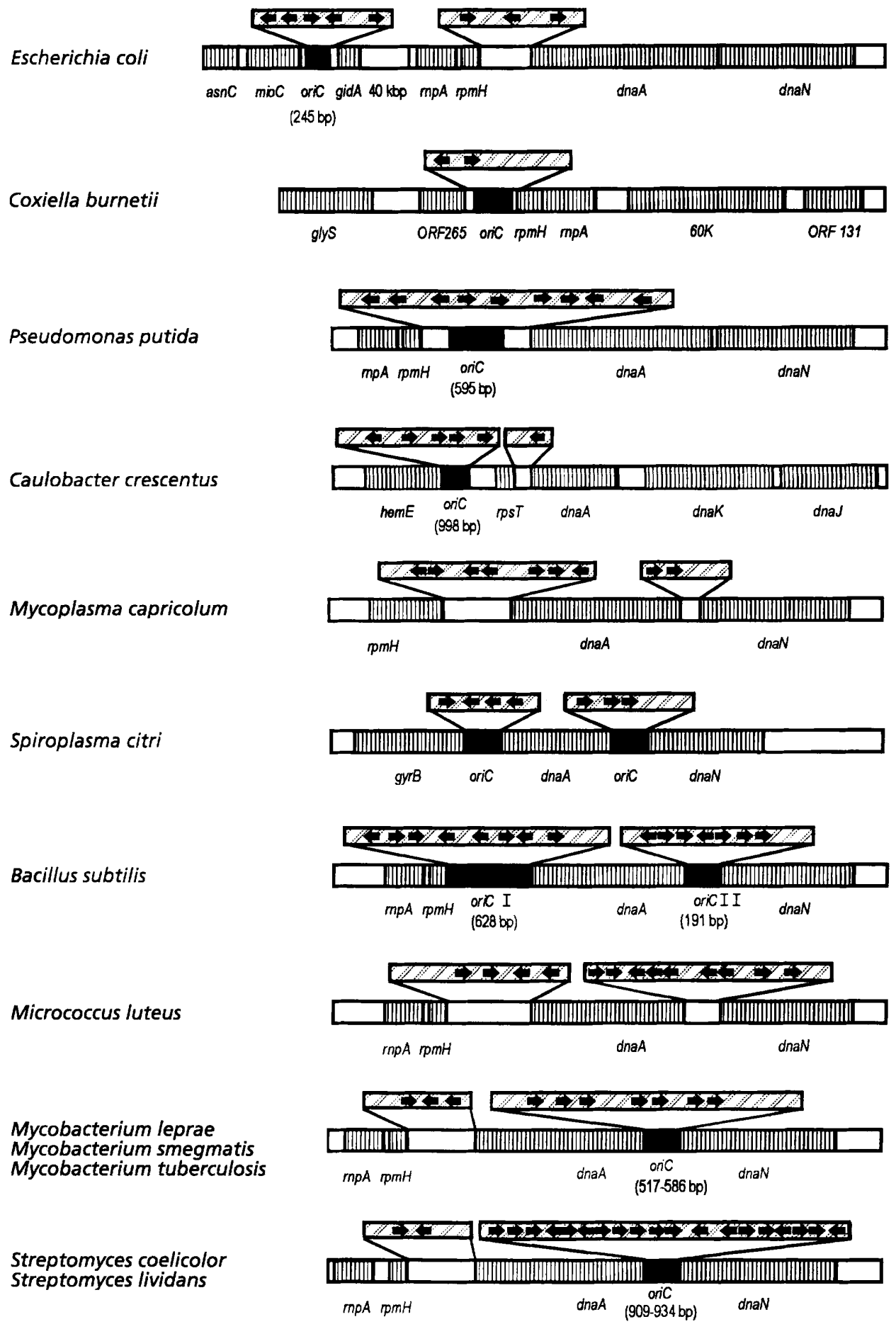

Fig. 1. Comparison of the genetic organization of the oriC region of different bacteria. DnaA boxes are indicated by arrows. References: Escherichia coli, von Meyenburg \& Hansen (1987); Coxiella burnetii, Shuan et al. (1994); Pseudomonas putida, Smith et al. (1991); Caulobacter crescentus, Marczyński \& Shapiro (1992); Mycoplasma capricolum, Fujita et al. (1992); Spiroplasma citri, Ye et al. (1994); Bacillus subtilis, Yoshikawa \& Wake (1993); Micrococcus luteus, Fujita et al. (1990); Mycobacterium leprae, Mycobacterium smegmatis, Mycobacterium tuberculosis, Salazar et al. (1996); Streptomyces coelicolor, Calcutt \& Schmidt (1992); Streptomyces lividans, Zakrzewska-Czerwinska \& Schrempf (1992), Zakrzewska-Czerwińska et al. (1994).

cluster of four or more DnaA boxes is an indication of a functional chromosomal origin. A putative oriC region from Coxiella burnetii contains only two DnaA boxes
(Fig. 1) (Shuan et al., 1994). However, it remains to be elucidated whether this region is able to promote autonomous replication. In Bacillus subtilis, two DnaA 
box clusters are arranged upstream and downstream of the $d n a A$ gene and act together as a replication origin (Fig. 1) (Yoshikawa \& Wake, 1993). DnaA is the key protein in the initiation of DNA replication in bacteria (Kornberg \& Baker, 1992; Skarstad \& Boye, 1994; Messer \& Weigel, 1996) and binds specifically to the DnaA box. The interaction of DnaA with its chromosomal origin is best understood in Escherichia coli. Five DnaA boxes are present within the $E$. coli ori $C$ region. Binding of 10-20 DnaA monomers promotes a local unwinding of the AT-rich region (Bramhill \& Kornberg, 1988; Messer \& Weigel, 1996). The unwound region provides the entry site for the DnaB/DnaC helicase complex, followed by other proteins required to form a replication fork (Kornberg \& Baker, 1992).

Most eubacteria contain a block of genes, dnaA-dnaNrecF-gyrB, encoding DnaA, the $\beta$-subunit of the DNA polymerase III holoenzyme, a product for recombination and the $\beta$-subunit of DNA gyrase, respectively (Messer \& Weigel, 1996). Within many bacteria, including $B$. subtilis (Yoshikawa \& Wake, 1993), Micrococcus luteus (Fujita et al., 1990), Mycobacterium spp. (Salazar et al., 1996), Mycoplasma capricolum (Fujita et al., 1992) and Pseudomonas putida (Smith et al., 1991), the oriC region is situated close to $d n a A$ (Fig. 1). However, within some bacteria the arrangement is different. The E. coli dnaA region is located about $40 \mathrm{~kb}$ away from oriC. In Coxiella burnetii, dnaA is absent within the putative oriC region (Fig. 1) (Shuan et al., 1994). The Caulobacter crescentus oriC is situated between hemE (encoding uroporphyrinogen decarboxylase) and $r p s T$ (encoding a homologue of the ribosomal protein $S 20$ ) and $2 \mathrm{~kb}$ away from $d n a A$ which is separated $(150 \mathrm{~kb})$ from the $d n a N$ recF-gyrB region (Marczyński \& Shapiro, 1992; Rizzio et al., 1993; Zweiger \& Shapiro, 1994). Sequences resembling other eubacterial oriC regions have not been detected in the vicinity of the $d n a A$ genes of Sinorbizobium meliloti (Margolin et al., 1995), Synechocystis sp. (Richter \& Messer, 1995) and Prochlorococcus marinus (Richter et al., 1998).

As in several other bacteria, the oriC region of Streptomyces lividans was identified as an autonomously replicating minichromosome (Zakrzewska-Czerwińska \& Schrempf, 1992; Zakrzewska-Czerwińska et al., 1995). It is situated between $d n a A$ and $d n a N$ and corresponds to the sequenced oriC region (Calcutt \& Schmidt, 1992) of the closely related strain $S$. coelicolor A3(2). Recent discoveries suggest that the chromosome of S. coelicolor A3(2) replicates bi-directionally (Musialowski et al., 1994) from the centrally located oriC (Radenbach et al., 1996) and its linear form is assumed to be patched up at the ends by protein-primed replication (Chen, 1996).

In this paper we have compared the characteristics of $S$. lividans oriC with cloned oriC regions from $S$. antibioticus and $S$. chrysomallus, and we have determined interactions of individual DnaA boxes with S. lividans DnaA.

\section{METHODS}

Bacterial strains, culture conditions and transformation. Streptomyces and E. coli strains used here are listed in Table 1. E. coli strains were grown in Luria-Bertani medium (Sambrook et al., 1989). Streptomyces strains were cultivated on agar plates containing complete medium until sporulation occurred (Hopwood et al., 1985). Spores were used to inoculate YEME liquid medium (Hopwood et al., 1985). Propagation and transformation of E. coli and Streptomyces strains were carried out as described by Hopwood et al. (1985) and Sambrook et al. (1989). Streptomyces spp. were selected for resistance to $10 \mu \mathrm{g}$ thiostrepton $\mathrm{ml}^{-1}$.

Plasmids and DNA library. Plasmids are listed in Table 1 . The $S$. chrysomallus genomic library in cosmid pV34 contains 32-34 kb DNA fragments obtained by partial Sau3A digestion of chromosomal DNA and cloned in the BamHI site of the vector (Pahl et al., 1992).

Chemicals, enzymes and oligonucleotides. Standard chemicals were obtained from Sigma or Serva. Restriction enzymes were supplied by Boehringer Mannheim, MBI Fermentas or Gibco-BRL. Oligonucleotides used for sequencing and PCR were chemically synthesized (MWG). For BIAcore studies, $5^{\prime}$ biotin-end-labelled oligonucleotides and their non-biotinylated complementary oligonucleotides were annealed by mixing equimolar amounts in $50 \mathrm{mM}$ Tris $/ \mathrm{HCl}, \mathrm{pH} 7 \cdot 5$, $100 \mathrm{mM} \mathrm{NaCl}, 0 \cdot 1 \mathrm{mM}$ EDTA, heating to $85^{\circ} \mathrm{C}$ and slowly cooling the samples to room temperature.

DNA isolation and manipulation. Total DNA was isolated from Streptomyces strains as described by Hopwood et al. (1985). Plasmid purification was done using a kit according to the manufacturer's protocols (Qiagen). The methods for the purification of DNA fragments, colony and Southern hybridization, and preparation of DNA probes have been described by Sambrook et al. (1989).

DNA sequence determination and computer analysis. DNA sequencing was performed using the dideoxy chain-termination method (Sanger et al., 1977) with Sequenase (USB) and $\left[\alpha^{-35}\right.$ S ATP (Amersham). The nucleotide sequence was determined on both strands. Computer analysis was done using the GCG package programs for ORF identification and sequence alignment.

PCR. Comparison of the amino acid sequences of DnaA and DnaN allowed selection of highly conserved motifs at the $C$ terminus of DnaA (FGGRDH) and the $\mathrm{N}$ terminus of DnaN (MKIRVER). Taking into account the known Streptomyces codon usage, two degenerate primers were deduced. The nucleotide sequences of the primers are as follows: $\mathrm{p}_{\mathrm{dnaA}}, 5^{\prime}$ CGCGGATCCTTCGGSGGSCGSGACCAC $3^{\prime} ; \mathrm{p}_{\mathrm{dnaN}}, 5^{\prime}$ AACTGCAGSCGCTCSACSCGGATCTTCAT $3^{\prime}$ ( $\mathrm{S}=\mathrm{G}$ or C). Each of them was tailed by a motif for a restriction site. PCR was done with 2.5 U Dynazyme II DNA polymerase (Finnzymes) in $50 \mu \mathrm{l}$ of the recommended buffer and was performed for 40 cycles $\left(10\right.$ cycles of $1 \mathrm{~min}$ at $95^{\circ} \mathrm{C}, 1 \mathrm{~min}$ at $50^{\circ} \mathrm{C}$ and $1.5 \mathrm{~min}$ at $72{ }^{\circ} \mathrm{C}$, and 30 cycles of $1 \mathrm{~min}$ at $95^{\circ} \mathrm{C}$, $1 \mathrm{~min}$ at $55^{\circ} \mathrm{C}$ and $1.5 \mathrm{~min}$ at $72^{\circ} \mathrm{C}$ ). Approximately $300 \mathrm{ng}$ genomic DNA from $S$. antibioticus ETH 7451 was used for PCR. The amplified products were analysed on a $1 \%$ agarose gel, purified with the QIAquick PCR purification kit (Qiagen), digested with restriction enzymes (Bam $\mathrm{HI}, P s t \mathrm{I})$ and then cloned in pUO9090.

Isolation of oriC fragments using affinity chromatography. The DNA-binding domain (BD) of S. lividans DnaA was fused 
Table 1. Bacterial strains and plasmids used in this study

\begin{tabular}{|c|c|c|}
\hline Strain or plasmid & Genotype and/or relevant characteristic ${ }^{*}$ & Reference \\
\hline \multicolumn{3}{|l|}{ Strains } \\
\hline E. coli AG115 & lacX74 galU galK araD139 strA hsdR17 F' lacl' lacZ::Tn5 & Mattern (1992) \\
\hline E. coli $\mathrm{DH} 5 \alpha$ & supE44 hsdR17 recA1 endA1 gyrA96 thi-1 relA1 & Sambrook et al. (1989) \\
\hline E. coli TG1 & $\begin{array}{l}\text { supE bsd } \Delta 5 \text { thi } \Delta\left(\text { lac-proAB) } \mathrm{F}^{\prime}\left[\operatorname{traD} 36 \text { proAB }{ }^{+} \text {lacl }\right.\right. \\
\text { lacZ } \mathrm{q} \text { M15] }\end{array}$ & Sambrook et al. (1989) \\
\hline E. coli WM2121 & ara $\Delta$ (lac-pro) fis:: Km recA56 rpsL srlC300:: Tn10 thi & Koch et al. (1988) \\
\hline S. antibioticus & ETH 7451 & Novella et al. (1992) \\
\hline S. chrysomallus & ATCC 11523 & \\
\hline S. lividans TK21 & SLP2- $^{-}$SLP3- derivative of S. lividans 66 & Hopwood et al. (1985) \\
\hline \multicolumn{3}{|l|}{ Plasmids } \\
\hline pBR322 & $A p^{r}, T c^{r}$ & Bolivar et al. (1977) \\
\hline pUC18 & $\mathrm{Ap}^{\mathrm{r}}$ & Yanisch-Perron et al. (1985) \\
\hline pUK21 & $\mathrm{Km}^{\mathrm{r}}$ & Vieira \& Messing (1991) \\
\hline pUO9090 & pUK21 derivative containing $1.5 \mathrm{~kb} \mathrm{Am}^{\mathrm{r}}$ & M. C. Martin (unpublished) \\
\hline pBluescript II SK(+) & pUC derivative (pMB1 replicon) & Short et al. (1988) \\
\hline pLEX3BT & tac promoter, $\mathrm{Ap}^{\mathrm{r}}$ & Diederich et al. (1994) \\
\hline pGEX-3X-6His & GST gene fusion vector, $A p^{r}$ & Majka et al. (1997a) \\
\hline pUSA1 & $\begin{array}{l}\text { pUO } 9090 \text { derivative containing } 934 \mathrm{bp} \mathrm{BamHI-Pst} \text { fragment of } \\
\text { the oriC region of } S \text {. antibioticus }\end{array}$ & This study \\
\hline pBSC1 & $\begin{array}{l}\text { pBR322 derivative containing } 4 \cdot 2 \mathrm{~kb} \text { Bam HI fragment of the } S \text {. } \\
\text { chrysomallus dnaA region }\end{array}$ & This study \\
\hline pBSC2 & $\begin{array}{l}\text { pBluescript II SK }(+) \text { derivative containing } 1228 \text { bp SacI-Bam } \mathrm{HI} \\
\text { fragment of the ori } C \text { region of } S \text {. chrysomallus }\end{array}$ & This study \\
\hline pBSL1 & $\begin{array}{l}\text { pBluescript II SK }(+) \text { derivative containing } 1092 \mathrm{bp} \text { SphI-BglII } \\
\text { fragment of the oriC region of S. lividans }\end{array}$ & Zakrzewska-Czerwińska et al. (1995) \\
\hline pGDnaA(BD) & $\begin{array}{l}\text { pGEX-3X-6His derivative containing } 432 \text { bp Xholl-XhoII-SphI } \\
\text { fragment encoding the DNA BD of } S \text {. lividans DnaA }\end{array}$ & Majka et al. (1997a) \\
\hline pLEXDnaA6xHis & $\begin{array}{l}\text { pLEXBT derivative containing the entire } S \text {. lividans } d \text { naA gene } \\
\text { and }(\mathrm{CACCAT})_{3} \text { encoding six histydyl residues at the } 3^{\prime} \text { end of } \\
\text { dnaA gene }\end{array}$ & Majka et al. (1997b) \\
\hline
\end{tabular}

*ATCC, American Type Culture Collection, Rockville, MD, USA. Am, apramycin; Ap, ampicillin; Km, kanamycin; Tc, tetracyclin.

to the C terminus of glutathione $S$-transferase (GST) as described previously (Majka et al., 1997a). Plasmid pGEXDnaA(BD), encoding the fusion protein GST-DnaA(BD), was transformed into $E$. coli AG115. Cells were grown for $3 \mathrm{~h}$ at $37^{\circ} \mathrm{C}$ to an $\mathrm{OD}_{550}$ of 0.6 in the presence of $100 \mu \mathrm{g}$ ampicillin $\mathrm{ml}^{-1}$ and then induced with $0.5 \mathrm{mM}$ IPTG for $1.5 \mathrm{~h}$. After centrifugation $\left(5000 \mathrm{~g}, 4{ }^{\circ} \mathrm{C}, 10 \mathrm{~min}\right)$, cells were resuspended in lysis buffer $(50 \mathrm{mM}$ Tris/ $\mathrm{HCl}, 100 \mathrm{mM} \mathrm{NaCl}, 1 \mathrm{mM}$ EDTA, $1 \mathrm{mM}$ PMSF, $\mathrm{pH} \mathrm{8.0)}$ and degraded by sonification (five times, $30 \mathrm{~s}$ each). After centrifugation $\left(30000 \mathrm{~g}, 4^{\circ} \mathrm{C}\right.$, $60 \mathrm{~min}$ ), the crude extract was treated with $25 \mu \mathrm{g} \mathrm{DNaseI} \mathrm{l^{-1 }}$ $\left(37^{\circ} \mathrm{C}, 30 \mathrm{~min}\right)$. The GST-DnaA(BD) fusion bound directly from the bacterial extract to the glutathione-Sepharose beads. The column was then washed with 10 bed volumes of lysis buffer. The DNA, digested with restriction endonuclease, was loaded onto the glutathione-Sepharose-GST-DnaA(BD) in 'low' salt buffer ( $20 \mathrm{mM}$ Tris/HCl, $100 \mathrm{mM} \mathrm{NaCl}, \mathrm{pH} 8 \cdot 0$ ). After $1 \mathrm{~h}$ incubation at room temperature, the column was washed with three column volumes of 'medium' salt buffer (20 mM Tris/ $\mathrm{HCl}, 500 \mathrm{mM} \mathrm{NaCl}, \mathrm{pH} \mathrm{8.0)}$ to remove DNA that did not tightly associate with the GST-DnaA(BD) beads. DNA that remained bound to the beads was then eluted with 'high' salt buffer (20 mM Tris/ $\mathrm{HCl}, 2000 \mathrm{mM} \mathrm{NaCl}, \mathrm{pH} 8 \cdot 0$ ), followed by 2-propanol precipitation. The DNA was re- suspended in TE buffer $(10 \mathrm{mM}$ Tris/ $\mathrm{HCl}, 1 \mathrm{mM}$ EDTA, $\mathrm{pH} 8)$ and analysed on an agarose gel.

Purification of $\boldsymbol{S}$. lividans DnaA. S. lividans DnaA was overexpressed in E. coli WM2121 as a His-tagged protein and then purified on a $\mathrm{Ni}^{2+}$-NTA-agarose column (Qiagen) as described previously (Majka et al., 1997b).

Surface plasmon resonance. The biotinylated doublestranded oligonucleotides were immobilized on a streptavidincoated SM 5A chip of the BIAcore apparatus. Usually, 100-250 RU (resonance units) of DNA was immobilized. DNA loosely attached to the surface of the chip was removed with $0.05 \%$ SDS. To exclude the effects of mass transfer on the kinetics of protein-DNA interactions, the measurements were performed at various protein concentrations $(17 \cdot 4-174 \mathrm{nM})$ and at three different flow rates $\left(2,5\right.$ and $\left.10 \mu \mathrm{min}^{-1}\right)$. The calculated kinetic constants did not differ significantly. Thus, the subsequent measurements were performed at a continuous flow of $2 \mu \mathrm{l} \mathrm{HBS}$ buffer $\mathrm{min}^{-1}$ (HBS buffer: $10 \mathrm{mM}$ HEPES, $\mathrm{pH} 7.4,150 \mathrm{mM} \mathrm{NaCl}, 3.4 \mathrm{mM}$ EDTA, 0.005\% BIAcore surfactant P20). At the end of each cycle, bound DnaA was removed by washing with $0.05 \%$ SDS. The BIAevaluation version 2.1 program (Pharmacia Biosensor) was utilized for data analysis. 


\section{RESULTS AND DISCUSSION}

\section{Cloning of the oriC regions of S. antibioticus and $S$. chrysomallus}

Comparisons of the deduced amino acid sequences of DnaA and DnaN from several bacteria, including $S$. lividans, showed two highly conserved motifs in the respective $\mathrm{C}$ - and $\mathrm{N}$-terminal regions. Two corresponding degenerate primers were deduced and used to amplify a DNA fragment ( $\sim 900 \mathrm{bp})$ from total $S$. antibioticus DNA. The fragment was cloned into pUO9090 to yield plasmid pUSA1 (Table 1). Hybridization with totally digested chromosomal DNA proved that the cloned fragment was derived from S. antibioticus (data not shown).

To isolate the oriC region of $S$. chrysomallus, a library of its genomic DNA in the cosmid vector pV34 (Pahl et al., 1992) was hybridized with a $1.2 \mathrm{~kb} B a m \mathrm{HI}-S p h \mathrm{I}$ fragment encoding the $\mathrm{C}$ terminus of $S$. lividans DnaA (Zakrzewska-Czerwińska et al., 1994). From 12000 colonies, eight positive clones were obtained. Within each of the cosmids a $4.2 \mathrm{~kb} \mathrm{BamHI}$ fragment hybridized with the $d n a A$ probe and cloning of this BamHI fragment in pBR322 gave pBSC1. Sequence analysis allowed the identification of the $3^{\prime}$ end of $d n a A$ and the $5^{\prime}$ end of dnaN. A $1.2 \mathrm{~kb} \mathrm{BamHI-SacI}$ fragment of pBSC1 containing the intergenic region between $d n a A$ and $d n a N$ (putative oriC region) was subcloned into pBluescript II $\mathrm{SK}(+)$, resulting in pBSC2. Hybridizations with three selected probes from the ori $\mathrm{C}$ region indicated a moderate homology among the cloned oriC regions (data not shown).

\section{Comparisons of the oriC regions}

The nucleotide sequence of the cloned putative oriC fragments was determined on both strands and subjected to computer analysis. The overall GC content of the analysed regions of $S$. antibioticus and S. chrysomallus is about $65 \%$ and $63 \%$, respectively (Table 2 ), and is thus, as in the S. lividans oriC region, approximately $10 \%$ lower than the mean GC content of known Streptomyces genes. The oriC regions of $S$. antibioticus and S. chrysomallus were flanked by $d n a A$ and $d n a N$ which are separated by 909 and 921 bp, respectively. A search for DnaA box motifs whose sequences differ up to $2 \mathrm{nt}$ from the preferred sequence (TTGTCCACA) (Zakrzewska-Czerwińska \& Schrempf, 1992) allowed identification of 19 putative DnaA boxes in each analysed oriC region (Fig. 2). Previously, 17 DnaA boxes had been identified within the oriC region of $S$. coelicolor A3(2) and S. lividans (Zakrzewska-Czerwińska \& Schrempf, 1992); the 9th and 13th DnaA boxes had not been found (Fig. 2). The position and orientation of each of the 19 deduced DnaA boxes are identical in $S$. antibioticus, S. chrysomallus and S. lividans (Fig. 2). Only the distance between DnaA boxes 9 and 10 in $S$. antibioticus is shorter ( $2 \mathrm{bp}$ ) than in S. chrysomallus and $S$. lividans $(12 \mathrm{bp})$. Alteration of the spacing between DnaA boxes inactivates replication activity of the $E$. coli origin. It is interesting that only mutants with an insertion or deletion of $10 \mathrm{bp}$ (close to a full helical turn) between the DnaA boxes R2 and R3, or R3 and R4 retain a functional oriC (Woelker \& Messer, 1993). In contrast, point mutations in the DnaA boxes of $E$. coli oriC sequence have a comparatively slight effect on replication (Langer et al., 1996). Thus, the location of the DnaA boxes with respect to the helix axis is apparently important. The short stretches of DNA flanking the individual boxes are more variable (about $60 \%$ identical) in the corresponding regions between the three Streptomyces species.

The 57 DnaA boxes were used to determine the consensus sequence ( $T / C)(T / C)(G / A C) T C C A C A$ (preferred bases in bold) (Table 3). The consensus sequence of the Streptomyces DnaA box is more variable than in other bacteria, similar to Mycobacterium (Salazar et al., 1996). As in other organisms, bases in positions 4 and 6 of the Streptomyces DnaA boxes were found to be highly conserved. C-5, A-7 and C-8 were also well conserved, in contrast to the third position which is the most variable.

Following the interaction of DnaA with DnaA boxes, a local unwinding occurs at specific AT-rich sequences, characteristic for a replication origin (Bramhill \& Kornberg, 1988; Gille \& Messer, 1991; Hsu et al., 1994). The partially unwound oriC then presumably provides the entry site for the replicative helicase. In E. coli, three AT-rich 13-mer direct repeats are localized in the $5^{\prime}$ part of the oriC region close to the first DnaA box. B. subtilis DnaA-mediated unwinding occurs in an AT-rich 27-mer adjacent to the DnaA boxes that are located downstream of dnaA (Moriya et al., 1994; Krause et al., 1997). None of the three Streptomyces oriC regions contains the ATrich repeats adjacent to clusters of DnaA boxes. However, each of the Streptomyces regions contains five

Table 2. Characteristics of the Streptomyces dnaA-dnaN intergenic region (oriC region)

\begin{tabular}{|c|c|c|c|c|c|c|}
\hline \multirow[t]{2}{*}{ Species } & \multirow[t]{2}{*}{$\begin{array}{c}\text { No. of DnaA } \\
\text { boxes }\end{array}$} & \multirow[t]{2}{*}{$\begin{array}{c}\text { GC content } \\
(\mathrm{mol} \%)\end{array}$} & \multirow[t]{2}{*}{$\begin{array}{l}\text { Length of oriC } \\
\text { region (bp) }\end{array}$} & \multicolumn{3}{|c|}{$\begin{array}{l}\text { Sequence similarities in the } \\
\text { oriC region }(\%)\end{array}$} \\
\hline & & & & 1 & 2 & 3 \\
\hline 1. S. antibioticus & 19 & $65 \cdot 2$ & 909 & 100 & 60 & 59 \\
\hline 2. S. chrysomallus & 19 & $63 \cdot 0$ & 921 & 60 & 100 & 63 \\
\hline 3. S. lividans & 19 & $63 \cdot 2$ & 934 & 59 & 63 & 100 \\
\hline
\end{tabular}




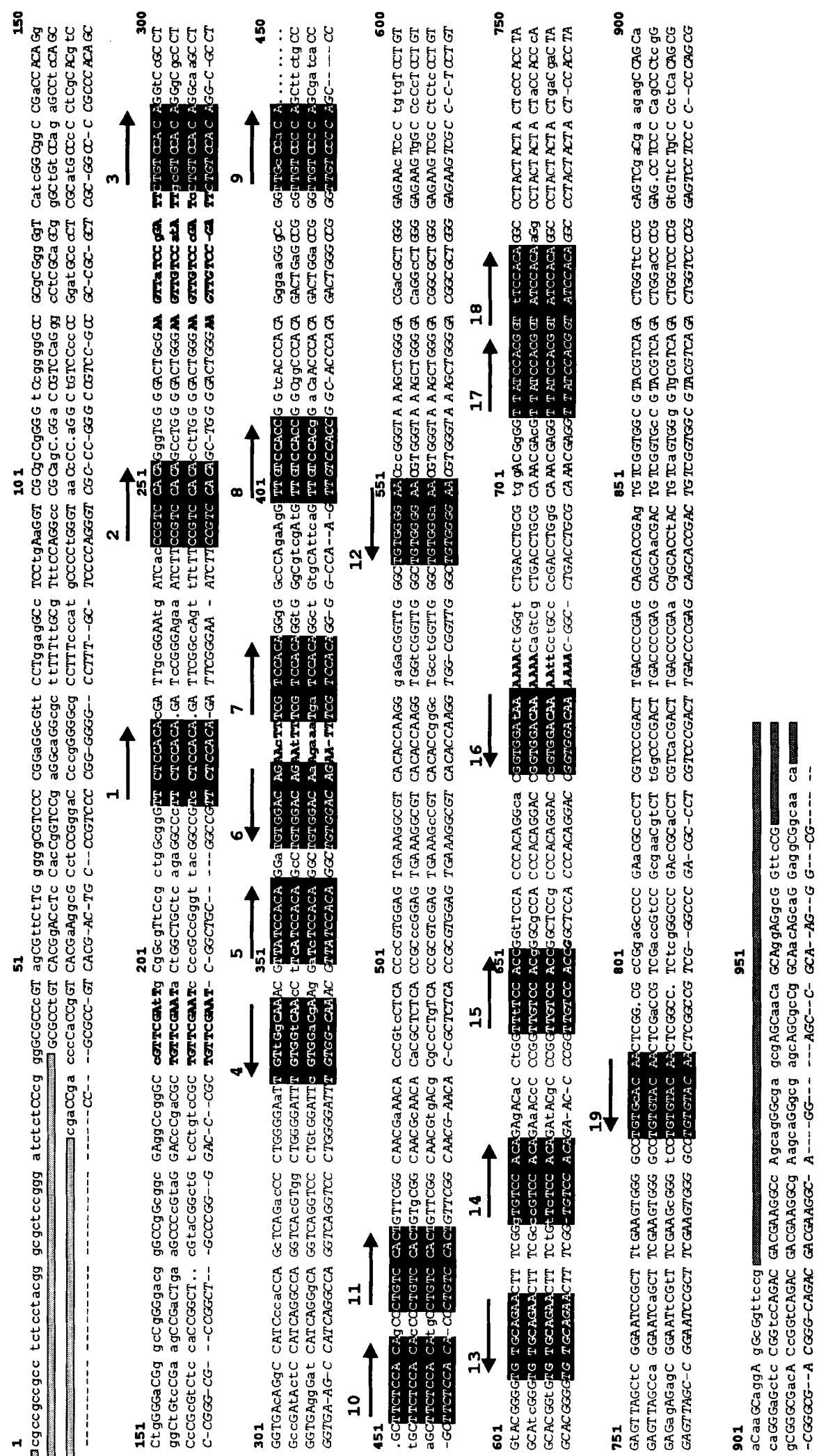

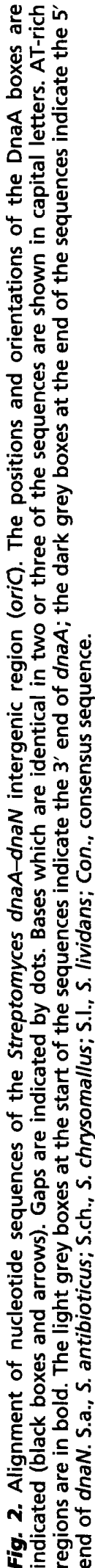

कं 
Table 3. Frequency of nucleotide usage in Streptomyces DnaA boxes

\begin{tabular}{|c|c|c|c|c|c|c|c|c|c|}
\hline \multirow[t]{2}{*}{ Nucleotide } & \multicolumn{9}{|c|}{ No. of times used in position no.: } \\
\hline & 1 & 2 & 3 & 4 & 5 & 6 & 7 & 8 & 9 \\
\hline A & 1 & 0 & 9 & 1 & 2 & 1 & 55 & 0 & 41 \\
\hline $\mathrm{C}$ & 11 & 10 & 13 & 5 & 51 & 56 & 2 & 57 & 6 \\
\hline G & 5 & 1 & 32 & 0 & 4 & 0 & 0 & 0 & 7 \\
\hline$T$ & 40 & 46 & 3 & 51 & 0 & 0 & 0 & 0 & 3 \\
\hline \multicolumn{10}{|l|}{ Consensus } \\
\hline Streptomyces spp. & $\mathbf{T} / \mathrm{C}$ & $\mathrm{T} / \mathrm{C}$ & ${ }^{A} / G_{/ C}$ & $\mathbf{T}$ & $\mathrm{C}$ & $\mathrm{C}$ & $\mathbf{A}$ & C & $\mathbf{A}$ \\
\hline Mycobacterium spp. & $\mathrm{T} / \mathrm{C}$ & $\mathbf{T}$ & $\mathrm{G} / \mathrm{A}$ & $\mathbf{T}$ & C & C & $\mathrm{A} / \mathrm{C}$ & C & $\mathbf{A}$ \\
\hline E. $\operatorname{coli}(\mathrm{a}) \dagger$ & $\mathbf{T}$ & $\mathbf{T}$ & $\mathrm{A} / \mathrm{T}$ & $\mathbf{T}$ & $\mathrm{N}$ & $\mathrm{C}$ & $\mathbf{A}$ & C & $\mathbf{A}$ \\
\hline E. coli $(\mathrm{b}) \dagger$ & $\mathbf{T}$ & $\mathrm{T} / \mathrm{C}$ & $\mathrm{A} / \mathrm{T}$ & $\mathbf{T}$ & $\mathrm{A} / \mathrm{C}$ & C & $\mathbf{A}$ & $\mathrm{C} / \mathrm{A}$ & $\mathbf{A}$ \\
\hline E. coli $(\mathrm{c}) \dagger$ & $\mathrm{T} / \mathrm{C}$ & $\mathrm{T} / \mathrm{C}$ & ${ }^{\mathbf{T}} \mathbf{A}_{/ \mathrm{C}}$ & $T$ & $\mathrm{~A} / \mathrm{C}$ & C & $\mathrm{A} / \mathrm{G}$ & ${ }^{A} C_{/ T}$ & $\mathbf{A}$ \\
\hline
\end{tabular}

*Numbers/letters in bold indicate the preferred sequence.

† Consensus sequences for the E. coli DnaA box were determined by three different methods: (a) binding constants measurements (Schaper \& Messer, 1995); (b) DNaseI footprinting analysis (Fuller $e t$ al., 1984); (c) in vivo analysis of the effects of DnaA on transcription termination (Schaefer \& Messer, 1991).

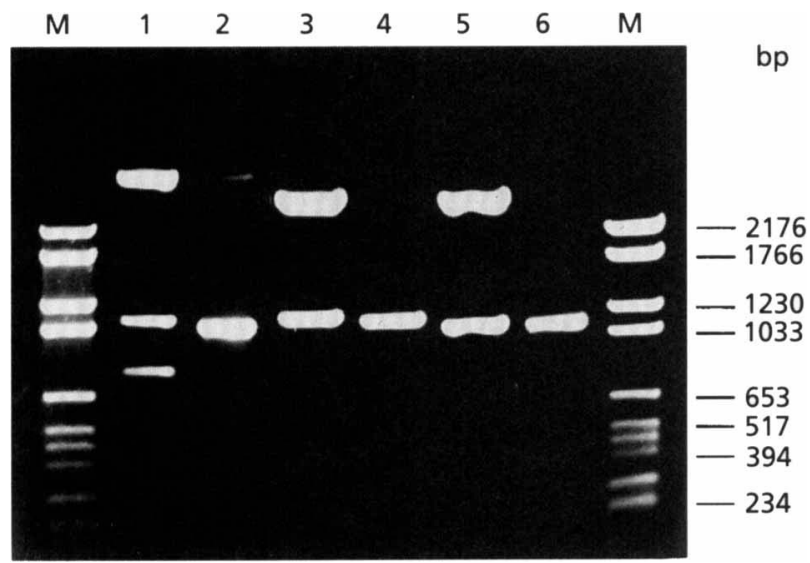

Fig. 3. DNA-binding assay-selective binding of an oriccontaining DNA fragment using GST-DnaA(BD) beads. Plasmid DNA $(1 \mu \mathrm{g})$ digested with Sall was bound to the beads. Fragments were analysed by agarose gel electrophoresis. Lanes: $1,3,5$, DNA loaded on the affinity column; 2, 4, 6, DNA specifically bound to the fusion protein and released from the beads by washing with 'high' salt buffer. The analysed DNA fragments were from $S$. antibioticus (lanes 1,2 ), S. chrysomallus $(3,4)$ and $S$. lividans $(5,6)$. Lanes $M$, standard size markers (Boehringer VI).

short AT-rich sequences that are located close to the $5^{\prime}$ end of the first DnaA box (positions 191-199), between the 1 st and 2 nd boxes $(230-245)$, between the 2 nd and 3rd boxes (269-282), between the 6th and 7th boxes (371-378) and following the 16th box in the $3^{\prime}$ flanking sequence (678-684) (Fig. 3). Repeated attempts to determine DnaA-mediated unwinding of oriC, using permanganate footprinting, have been unsuccessful (data not presented). S. lividans DnaA differs from the corresponding E. coli protein in its acquisition of an additional stretch of 120 predominantly acidic amino acids in domain II (Majka et al., 1997b). It remains to be elucidated whether the acidic domain II interacts with putative accessory basic proteins which help in the unwinding of oriC.

The $S$. chrysomallus minichromosome replicates in $S$. lividans. However, similar to the minichromosomes of S. lividans, B. subtilis and Mycobacterium tuberculosis, it is unstable and present only in low copy numbers. This apparent incompatibility could be caused by the competition of the same replicons for DnaA. Thus, as in B. subtilis (Moriya et al., 1994), the initiation of Streptomyces oriC replication appears to be tightly controlled.

\section{Interaction of DnaA with DnaA boxes}

To test whether the previously characterized $S$. lividans DnaA protein binds to the cloned Streptomyces oriC fragments, a recently described DNA-binding assay was performed (Majka et al., 1997a). The fusion protein, consisting of the BD of DnaA and GST, was fixed to glutathione-Sepharose beads and its specific interactions with the cloned oriC fragments were tested (Fig. 3). Each of the cloned DNA fragments of $S$. antibioticus and $S$. chrysomallus, as well the previously characterized oriC of S. lividans (control), was selectively bound to the GST-DnaA(BD) fusion protein.

His-tagged S. lividans DnaA (Majka et al., 1997b) was investigated for its binding properties with respect to various DnaA boxes. To evaluate the interactions of 
Table 4. Kinetic rate constants for the binding of DnaA to DnaA boxes

\begin{tabular}{|c|c|c|c|c|}
\hline \multirow[t]{2}{*}{ DnaA box ${ }^{*}$} & \multirow[t]{2}{*}{ Sequence $\left(5^{\prime}-3^{\prime}\right) \dagger$} & \multicolumn{3}{|c|}{ Kinetic constants $\ddagger$} \\
\hline & & $k_{\text {on }}\left(M^{-1} s^{-1}\right)$ & $k_{\text {off }}\left(s^{-1}\right)$ & $K_{\mathrm{D}}(\mathrm{n} \mathbf{M}) \mathbb{S}$ \\
\hline $1_{\mathrm{dnaA}}=6_{\text {oric }}$ & GAGACACTTGTCCACACAACTTG & $1.2 \times 10^{6}$ & $1.4 \times 10^{-2}$ & 12 \\
\hline $2_{\text {dnaA }}$ & GAGACACTGGGGACAACAACTTG & - & - & - \\
\hline 2 & GTTTTTTCCGTCCACACCTTGGG & $5.0 \times 10^{5}$ & $3.9 \times 10^{-2}$ & 78 \\
\hline $4_{\text {oric }}$ & GTGGATTCGTGGACGAAGAAATG & - & - & - \\
\hline $5_{\text {oric }}$ & GTGGATTATCTCCACAAGAAATG & $6.3 \times 10^{6}$ & $2.0 \times 10^{-2}$ & 32 \\
\hline $10_{\text {oric }}$ & CACCAGCTTCTCCACATGCCTGT & - & - & - \\
\hline $12_{\text {oric }}$ & GTTGGGCTGTGGGAAACGTGGT & - & - & - \\
\hline $17_{\text {oric }}$ & AACGAGGTTATCCACGGTATCCA & - & - & - \\
\hline Nonsense box & TTGTGCGATATAGTTCTCCGA & - & - & - \\
\hline
\end{tabular}

" The numbering of DnaA boxes is derived from the oriC region according to Fig. 3 ; the promoter region of the $S$. lividans dnaA gene contains two DnaA boxes: $1_{\text {dnaA }}$ and $2_{\text {dnaA }}$ (Zakrzewska-Czerwińska et al., 1994).

† Bold letters indicate the region of specific recognition (DnaA box).

$\neq-$, non-specific binding $\left(K_{\mathrm{D}}>200 \mathrm{nM}\right)$.

$\$ K_{\mathrm{D}}=k_{\mathrm{orr}} / k_{\mathrm{on}}$.

DnaA with individual DnaA boxes, as well as possible effects of adjacent DnaA boxes, surface plasmon resonance (for review, see Bondeson et al., 1993; Malmqvist, 1993) was used. The major advantage of this technique is that protein-DNA interactions can be monitored in real time. Association and dissociation constants are subsequently recorded in the same experiment. A gel retardation assay is hampered by the need for recording a rapid reaction with a small number of data points. A technical difficulty is the lag time from loading of the sample onto the gel to the separation of free and bound reactants (Bondeson et al., 1993). In contrast to surface plasmon resonance, gel retardation assays do not provide a real-time picture of the association events.

Oligonucleotides containing single DnaA boxes were synthesized (Table 4) and constructed in such a way that the DnaA box was flanked either on one side $\left(4_{\text {oric }}\right.$, $\left.5_{\text {oriC }}, 1_{\text {dnaA }} / 6_{\text {oric }}, 2_{\text {dnaA }}\right)$ or on both sides $\left(2_{\text {oric }}, 10_{\text {oric }}\right.$, $12_{\text {oriC }}, 17_{\text {oriC }}$ ) by corresponding sequences from oriC or from the dnaA promoter. As a control for non-specific binding, a duplex oligonucleotide with a scrambled consensus sequence was included (Table 4). The oligonucleotides were then treated with varying concentrations of DnaA. The kinetic parameters for the binding of DnaA to the DnaA box were deduced from sensograms (Fig. 4 and by similar experiments) using the BIAevaluation version 2.1 program. The shape of the sensograms for the scrambled oligonucleotide was not dependent on DnaA concentration (data not shown). The curves obtained for the scrambled oligonucleotide were subtracted from the curves obtained for the oligonucleotide containing the DnaA box.

All sensograms were monophasic and could therefore be assumed to follow a pseudo-first-order kinetic model.

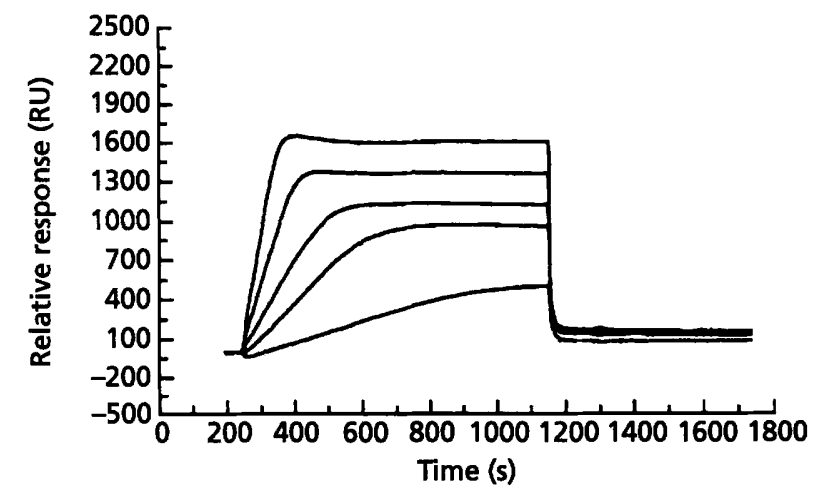

Fig. 4. Plasmon surface resonance studies. Sensograms obtained at different concentrations of DnaA interacting with a DNA fragment containing DnaA box $1_{\text {dnaA }} / 6_{\text {oric. }}$. The biotinylated double-stranded oligonucleotide was immobilized on a streptavidin-coated chip of the BIAcore apparatus, as described in Methods. From bottom to top, the concentration of DnaA was $17 \cdot 4,43 \cdot 3,87,108$ and $174 \mathrm{nM}$, respectively.

The apparent $k_{\text {off }}$ and $k_{\text {on }}$ rate constants were determined from the association and dissociation curves, respectively. $k_{\text {off }}$ and $k_{\text {on }}$ were calculated by fitting the data to the equations $R=R_{0} \mathrm{e}^{-k_{\text {off }}\left(t-t_{0}\right)}$ and $R=$ $R_{\text {eq }}\left[1-\mathrm{e}^{-\left(k_{\text {on }} C+k_{\text {off }}\right)\left(t-t_{0}\right)}\right]$ where $R_{0}$ is the initial response, $R_{\text {eq }}$ is the response at equilibrium and $C$ is the molar concentration of protein in solution (BIAevaluation software handbook, 1996; BIAcore). Since the response is directly proportional to the concentration of complexes formed, the response value $(R)$ may be used without conversion. The $k_{\text {off }}$ and $k_{\text {on }}$ values obtained at different protein concentrations did not vary signifi- 
cantly. The equilibrium dissociation constant, $K_{\mathrm{D}}$, was calculated as the ratio between dissociation and association rate constants $\left(k_{\text {off }} / k_{\text {on }}\right)$ (Table 4$)$.

Only three of the eight individual DnaA boxes analysed $\left(2_{\text {oric }}, 5_{\text {oriC }}\right.$ and $\left.1_{\text {dnaA }} / 6_{\text {oric }}\right)$ exhibited specific binding of DnaA; the $K_{\mathrm{D}}$ varied between 12 and $78 \mathrm{nM}$ (Table 4). Similar values were obtained by mobility shift assay (data not shown). The DnaA box with the 'perfect' sequence (TTGTCCACA) showed the highest affinity to DnaA $(12 \mathrm{nM})$. DnaA boxes $2_{\text {dnaA }}, 4_{\text {oric }}, 12_{\text {oric }}$ and $17_{\text {oric }}$, which differ from the consensus at highly conserved positions (4, 7 and 9), were not recognized specifically by DnaA, i.e. the $K_{\mathrm{D}}$ was $>200 \mathrm{nM}$. DnaA box $10_{\text {oric }}$ was not bound specifically by DnaA, despite the fact that its sequence differs by one base from the consensus at the most variable third position. Different techniques were employed to define the consensus sequence of the E. coli DnaA box (Table 3). Having determined the equilibrium binding constant by gel retardation, the consensus sequence $\mathrm{TT}(\mathrm{A} / \mathrm{T})$ TNCCACA was stringently defined (Schaper \& Messer, 1995). It corroborates the fact that the DnaA box $10_{\text {oric }}$ ( $C$ is at the third position instead of $A$ or $T$ ) was not specifically recognized by DnaA.

Future studies are planned to elucidate the initiation of replication of Streptomyces oriC, which is more complex than the corresponding process in E. coli.

\section{ACKNOWLEDGEMENTS}

This work was supported by grant Me659/5-1 of the Deutsche Forschungsgemeinschaft, by the Polish Committee of Scientific Studies (KBN, grant 0482/P2/93/05) and by grant PB95-1057, Programa Sectorial de PGC, Subdirección General de Formación Promoción del Conocimiento, MEC, Spain. We are especially grateful to Martina Lemme for help in manuscript preparation.

\section{REFERENCES}

Bolivar, F., Rodriguez, R. L., Greene, P. J., Betlach, M. C., Heyneker, H. L., Boyer, H. W., Crosa, J. H. \& Falkow, S. (1977). Construction and characterization of new cloning vehicles. II. A multipurpose cloning system. Gene 2, 95-113.

Bondeson, K., Frostell-Karlsson, A., Fagerstam, L. \& Magnusson, G. (1993). Lactose repressor-operator DNA interactions: kinetic analysis by a surface plasmon resonance biosensor. Anal Biochem 214, 245-251.

Bramhill, D. \& Kornberg, A. (1988). Duplex opening by DnaA protein of novel sequences in initiation of replication at the origin of the E. coli chromosome. Cell 52, 743-755.

Calcutt, M. J. \& Schmidt, F. J. (1992). Conserved gene arrangement in the origin region of the Streptomyces coelicolor chromosome. $J$ Bacteriol 174, 3220-3226.

Chen, C. W. (1996). Complications and implications of linear bacterial chromosomes. Trends Genet 12, 192-196.

Diederich, L., Roth, A. \& Messer, W. A versatile plasmid vector system for the expression of genes in Escherichia coli. BioTechniques 16, 916-923.

Fujita, M. Q., Yoshikawa, H. \& Ogasawara, N. (1990). Structure of the dnaA region of Micrococcus luteus: conservation and variations among eubacteria. Gene 93, 73-78.
Fujita, M. Q., Yoshikawa, H. \& Ogasawara, N. (1992). Structure of the dnaA and DnaA-box region in the Mycoplasma capricolum chromosome: conservation and variations in the course of evolution. Gene 110, 17-23.

Fuller, R. S., Funnell, B. E. \& Kornberg, A. (1984). The DnaA protein complex with the $E$. coli chromosomal origin (oriC) and other sites. Cell 38, 889-900.

Gille, H. \& Messer, W. (1991). Localized unwinding and structural perturbations in the origin of replication, oriC, of Escherichia coli in vitro and in vivo. EMBO $J$ 10, 1579-1584.

Hopwood, D. A., Bibb, M. J., Chater, K. F., Kieser, T., Bruton, C. J., Kieser, H. M., Lydiate, D. J., Smith, C. P., Ward, J. M. \& Schrempf, H. (1985). Genetic Manipulation of Streptomyces: a Laboratory Manual. Norwich: John Innes Foundation.

Hsu, J., Bramhill, D. \& Thompson, Ch. M. (1994). Open complex formation by DnaA initiation protein at the Escherichia coli chromosomal origin requires the 13 -mers precisely spaced relative to the 9-mers. Mol Microbiol 11, 903-911.

Koch, C., Vandekerhove, J. \& Kahmann, R. (1988). Escherichia coli host factor for site-specific DNA inversion: Cloning and characterization of the fis gene. Proc Natl Acad Sci USA 85, 4237-4241.

Kornberg, A. \& Baker, T. (1992). DNA Replication, 2nd edn. New York: W. H. Freeman.

Krause, M., Rückert, B., Lurz, R. \& Messer, W. (1997). Complexes at the replication origin of Bacillus subtilis with homologous and heterologous DnaA protein. J Mol Biol 274, 365-380.

Kutzner, H. J. (1981). The family Streptomycetaceae. In The Prokaryotes: A Handbook on Habitats, Isolation and Identification of Bacteria, pp. 2028-2090. Edited by M. P. Starr, H. Stolp, H. G. Trüper, A. Balows \& H. Schlegel. Berlin: Springer.

Langer, U., Richter, S., Roth, A., Weigel, Ch. \& Messer, W. (1996). A comprehensive set of DnaA-box mutations in the replication origin, oriC, of Escherichia coli. Mol Microbiol 21, 301-311.

Leblond, P., Redenbach, M. \& Cullumn, J. (1993). Physical map of the Streptomyces lividans 66 genome and comparison with that of the related strain Streptomyces coelicolor A3(2). J Bacteriol 175, 3422-3429.

Lezhava, A., Mizukami, T., Kajitani, T., Kameoka, D., Redenbach, M., Shinkawa, H., Nimi, O. \& Kinashi, H. (1995). Physical map of the linear chromosome of Streptomyces griseus. J Bacteriol 177, 6492-6498.

Lin, Y.-S., Kieser, H. M., Hopwood, D. A. \& Chen, C. W. (1993). The chromosomal DNA of Streptomyces lividans 66 is linear. Mol Microbiol 10, 923-933.

Majka, J., Jakimowicz, D., Zarko-Postawka, M. \& ZakrzewskaCzerwinska, J. (1997a). Glutathione $S$-transferase fusion proteins as an affinity reagent for rapid isolation of specific sequence directly from genomic DNA. Nucleic Acids Res 25, 2537-2538.

Majka, J., Messer, W., Schrempf, H. \& Zakrzewska-Czerwińska, J. (1997b). Purification and characterization of the Streptomyces lividans initiator protein DnaA. J Bacteriol 179, 2426-2432.

Malmqvist, M. (1993). Biospecific interaction analysis using biosensor technology. Nature 361, 186-187.

Marczyński, G. T. \& Shapiro, L. (1992). Cell-cycle control of a cloned chromosomal origin of replication from Caulobacter crescens. J Mol Biol 226, 959-977.

Margolin, W., Bramhill, D. \& Long, S. R. (1995). The dnaA gene of Rhizobium meliloti lies within unusual gene arrangement. $J$ Bacteriol 177, 2892-2900.

Mattern, S. (1992). Regulation of the galactose operon of 
Streptomyces lividans. $\mathrm{PhD}$ Thesis. Universität Osnabrück, Osnabrück, Germany.

Messer, W. \& Weigel, C. (1996). Initiation of chromosome replication. In Escherichia coli and Salmonella typhimurium: Cellular and Molecular Biology, pp. 1579-1601. Edited by F. C. Neidhardt, J. L. Ingraham, K. Brooks Low, B. Magasanik, M. Schaechter \& H. E. Umbarger. Washington, DC: American Society for Microbiology.

von Meyenburg, K. \& Hansen, F. G. (1987). Regulation of chromosome replication. In Escherichia coli and Salmonella typhimurium: Cellular and Molecular Biology, pp. 1555-1577. Edited by F. C. Neidhardt, J. L. Ingraham, K. Brooks Low, B. Magasanik, M. Schaechter \& H. E. Umbarger. Washington, DC: American Society for Microbiology.

Moriya, S., Firshein, W., Yoshikawa, H. \& Ogasawara, N. (1994). Replication of a Bacillus subtilis oriC plasmid in vitro. Mol Microbiol 12, 469-478.

Musialowski, M. L., Flett, F., Scott, G. B., Hobbins, G., Smith, C. P. \& Oliver, S. G. (1994). Functional evidence that the principal DNA replication origin of the Streptomyces coelicolor chromosome is close to the dnaA-gyrB region. J Bacteriol 176, 5123-5125.

Novella, I. S., Barbes, C. \& Sanchez, J. (1992). Sporulation of Streptomyces antibioticus ETHZ 7451 in submerged culture. Can J Microbiol 38, 769-773.

Pahl, A., Ühlein, M., Bang, H., Schlumbohm, W. \& Keller, U. (1992). Streptomycetes possess peptidyl-prolyl cis-trans isomerases that strongly resemble cyclophilins from eukaryotic organisms. Mol Microbiol 6, 3551-3558.

Radenbach, M., Kieser, H. M., Denapaite, D., Eicher, A., Cullumn, J., Kinashi, H. \& Hopwood, D. A. (1996). A set of ordered cosmids and detailed genetic and physical map for the $8 \mathrm{Mb}$ Streptomyces coelicolor A3(2) chromosome. Mol Microbiol 21, 77-96.

Richter, S. \& Messer, M. (1995). Genetic structure of the dnaA region of the cyanobacterium Synechocystis sp. strain PCC6803. J Bacteriol 177, 4245-4251.

Richter, S., Hess, W. R., Krause, M. \& Messer, W. (1998). Unique organization of the $d n a A$ region from Procblorococcus marinus CCMP 1375, a marine cyanobacterium. Mol Gen Genet (in press).

Rizzio, M., Shapiro, L. \& Gober, J.W. (1993). Asymmetric expression of the DNA gyrase B subunit gene from replicationcompetent chromosome in the Caulobacter predivisional cell. $J$ Bacteriol 175, 6970-6981.

Salazar, L., Fsihi, H., de Rossi, E., Riccardi, G., Rios, C., Cole, S. T. \& Takiff, H. E. (1996). Organization of the origins of replication of the chromosomes of Mycobacterium tuberculosis and isolation of a functional origin from M. smegmatis. Mol Microbiol 20, 283-293.

Sambrook, J., Fritsch, E. F. \& Maniatis, T. (1989). Molecular Cloning: a Laboratory Manual, 2nd edn. Cold Spring Harbor, NY: Cold Spring Harbor Laboratory.

Sanger, F., Nicklen, S. \& Coulson, A. R. (1977). DNA sequencing with chain-terminating inhibitors. Proc Natl Acad Sci USA 74, $5463-5467$.
Schaefer, C. \& Messer, W. (1991). DnaA protein DNA interaction. Modulation of the recognition sequence. Mol Gen Genet 226, 34-40.

Schaper, S. \& Messer, W. (1995). Interaction of the initiator protein DnaA of Escherichia coli with its DNA target. $J$ Biol Chem 270, 17622-17626.

Short, J. M., Fernandez, J. M., Sorge, J. A. \& Huse, W. D. (1988). A bacteriophage lambda expression vector with in vivo excision properties. Nucleic Acids Res 16, 7583-7600.

Shuan, M., Chen, S.-Y., Thompson, H. A., Hoover, T. A., Hill, A. \& Williams, J. C. (1994). Cloning and characterization of an autonomous replication sequence from Coxiella burnetii. $J$ Bacteriol 176, 5233-5243.

Skarstad, K. \& Boye, E. (1994). The initiator protein DnaA: Evolution, properties and function. Biochim Biophys Acta 1217, 111-130.

Smith, D. W., Yee, T. W., Baird, C. \& Krishnapillai, V. (1991). Pseudomonad replication origins: a paradigm for bacterial origins? Mol Microbiol 5, 2581-2587.

Vieira, J. \& Messing, J. (1991). New pUC-derived cloning vectors with different selectable markers and DNA replication origins. Gene 100, 189-194.

Woelker, B. \& Messer, W. (1993). The structure of the initiation complex at the replication origin, oriC, of Escherichia coli. Nucleic Acids Res 21, 5025-5033.

Yanisch-Perron, C., Vieira, J. \& Messing, J. (1985). Improved M13 phage cloning vectors and host strains : nucleotide sequences of the M13mp18 and pUC19 vectors. Gene 33, 103-119.

Ye, F., Renaudin, J., Bove, J.-M. \& Laigret, F. (1994). Cloning and sequencing of the replication origin (oriC) of the Spiroplasma citri chromosome and construction of autonomously replicating artificial plasmids. Curr Microbiol 29, 23-29.

Yoshikawa, H. \& Ogasawara, N. (1991). Structure and function of DnaA and the DnaA-box in eubacteria: evolutionary relationships of bacterial replication origins. Mol Microbiol 5, 2589-2597.

Yoshikawa, H. \& Wake, R. G. (1993). Initiation and termination of chromosome replication. In Bacillus subtilis and Gram-Positive Bacteria: Biochemistry, Physiology and Molecular Genetics, pp. 507-528. Edited by A. L. Sonenshein, J. A. Hoch \& R. Losick. Washington, DC: American Society for Microbiology.

Zakrzewska-Czerwinska, J. \& Schrempf, H. (1992). Characterization of an autonomously replicating region from Streptomyces lividans. J Bacteriol 174, 2688-2693.

Zakrzewska-Czerwiniska, J., Nardmann, J. \& Schrempf, H. (1994). Inducible transcription of the $d n a A$ gene from Streptomyces lividans 66. Mol Gen Genet 242, 440-447.

Zakrzewska-Czerwińska, J., Majka, J. \& Schrempf, H. (1995). Minimal requirements of the Streptomyces lividans 66 oriC region, and its transcriptional and translational activities. $J$ Bacteriol 177, 4765-4771.

Zweiger, G. \& Shapiro, L. (1994). Expression of Caulobacter dnaA as a function of the cell cycle. J Bacteriol 176, 401-408.

Received 6 October 1997; revised 8 January 1998; accepted 14 January 1998. 